British Journal of Marketing Studies

Vol. 10, Issue 1, pp.47-63, 2022

Print ISSN: 2053-4043(Print),

Online ISSN: 2053-4051(Online)

\title{
SERVICE QUALITY AND BRAND LOYALTY OF BANKS IN BAYELSA STATE OF NIGERIA
}

\author{
Lyndon M. Etale ${ }^{1}$ and Emmanuel N. Jerry ${ }^{2}$ \\ ${ }^{1}$ Department of Accounting, Faculty of Management Sciences, Niger Delta University, \\ Wilberforce Island, Bayelsa State, Nigeria \\ 2Department of Marketing, Faculty of Management Sciences, Niger Delta University, \\ Wilberforce Island, Bayelsa State, Nigeria
}

Citation: Lyndon M. Etale and Emmanuel N. Jerry (2022) Service Quality and Brand Loyalty of Banks in Bayelsa State of Nigeria, British Journal of Marketing Studies, Vol. 10, Issue 1, pp.47-63

\begin{abstract}
The study was embarked upon with the aim of determining the nature of the relationship between service quality and brand loyalty of banks in Bayelsa State of Nigeria, and this was done using responsiveness and reliability as dimensions of service quality and brand advocacy as a measure of brand loyalty, bringing about two research questions and study hypotheses which was put to the test by the use of the Pearson correlation coefficient method with the aid of SPSS software. The study adopted the descriptive design and used a questionnaire as a means of gathering data from the customers of selected banks in Bayelsa State amounting to a total of 140, but a total of 130 copies of the questionnaire were retrieved and used for the analysis of data which informed the conclusion and findings of the research. The study revealed a significant relationship between both reliability and responsiveness as dimensions of service quality and brand advocacy as a measure of brand loyalty. The study therefore concluded that there is a significant relationship between the variables and thus made the following recommendations; Banks should give prompt and quick response to its customers "compliant by creating a simple and fast compliant handling system; Banks must let its customers feel safe and secured in any transaction; Banks should create a strong feedback system that enables them to relate effectively with customers and understand them better; Banks should fasten their service processes.
\end{abstract}

KEYWORDS: brand advocacy, brand loyalty, reliability, responsiveness, service quality

\section{INTRODUCTION}

The importance of brand loyalty to the operations and functionality of firms is linked directly with relationship marketing, which focuses on building a strong relationship with customers that causes them to constantly return to that firm to transact. In this era where businesses cannot be limited by just one-off sales, or by the transactional marketing mindset, it is important for the businesses to fully understand how and why customers become loyal to their brand, and how this can influence the operations and performance of the firm. This is even more visible in the service industry (Santouridis \& Trivellas, 2010).

@ECRTD-UK https://www.eajournals.org/ Journal level DOI https://doi.org/10.37745/bjms.2013 
With a view for the understanding of the value of the image and name of a firm, research was made to study Brand Equity, which is the value of a brand name and image. Brand equity sought to understand the capital contributions of the name and image of the firm as viewed by customers of the firm. Aaker (1991) in his work, went further to classify brand equity into four dimensions; Brand Associations, Brand Awareness, Perceived Quality, And Brand Loyalty. Of these four dimensions identified by Aaker, three of them have gone on to be widely researched. The three dimensions widely studied are brand associations, perceived quality, and brand loyalty. Aaker (1991) posits that brand loyalty is at the center of brand equity. Brand loyalty has been the focus of a wide range of research, spanning over 4 decades, and all pointing to the validity of developing brand loyalty over engaging in advertisement, and this is captured in the statistical evidence that says it is 6 times more expensive to acquire a new customer than to retain one (Rosenberg \& Czepiel, 1984). In addition to this standing, Giddens N. (2002) stands to establish that brand loyalty is the disposition of customers to repeatedly purchase from a particular brand in a product or service group at high prices, and also recommend that brand to others.

The necessity for understanding brand loyalty is becoming more of a focus as it keeps the brand in the heart of the consumers, and causes the customers to constantly stand on the side of defending and speaking for the interest of the firms which they are loyal to. This throws a new focus on the increased difficulty to pry customers from brands that already have the loyalty of customers, and also the cost implication as highlighted by Rosenberg and Czepiel, (1984). It therefore becomes expedient that ample research is done to fully understand the subject of brand loyalty, through all possible lenses, so as to fully grasp the dynamics of the subject and how it can be moderated and utilized for the benefit of all firms in a particular context.

\section{Statement of the Problem}

In every sector of the economy, especially the service-oriented ones, brand loyalty is a major player in determining the operationality or performance of that firm. This is because service-oriented firms must strive to understand their clients and how best to portray or create a good image or reputation as a service isn't perceived differently from the party engaged in the performance of the service, and how this can help in retaining customers and making them loyal to a brand. Research has been carried out by scholars, which points to the fact that brand loyalty has a direct impact on the brand equity of a firm, which invariably affects the value of that firm (Aaker, 1991).

Many studies have been done by researchers to understand the determinants and dynamics of brand loyalty (Saif, T., Ahmed, M., Shareef, S. \& Khalid, R., 2018; Chang and Wildt, 1994; Ennew \& Binks, 1999; Hallowell, 1996; Gotlieb et al., 1994; Patterson \& Spreng, 1997), and have succeeded in identifying three broad categories of determinants of brand loyalty which are; brand perceived value model; customer satisfaction model; and the service quality model. These models focused on how the customers perceived the firm and its product offerings. Ercis et al., (2012), went further to identify two major determinants of brand loyalty, customer satisfaction and brand commitment, which have a greater impact when compared to the impact of brand satisfaction. This was taken a 
Vol. 10, Issue 1, pp.47-63, 2022

Print ISSN: 2053-4043(Print),

Online ISSN: 2053-4051(Online)

step further by Yousaf et al. (2012), who established that there is a positive relationship between brand image, brand credibility, and brand loyalty.

\section{Conceptual Framework}

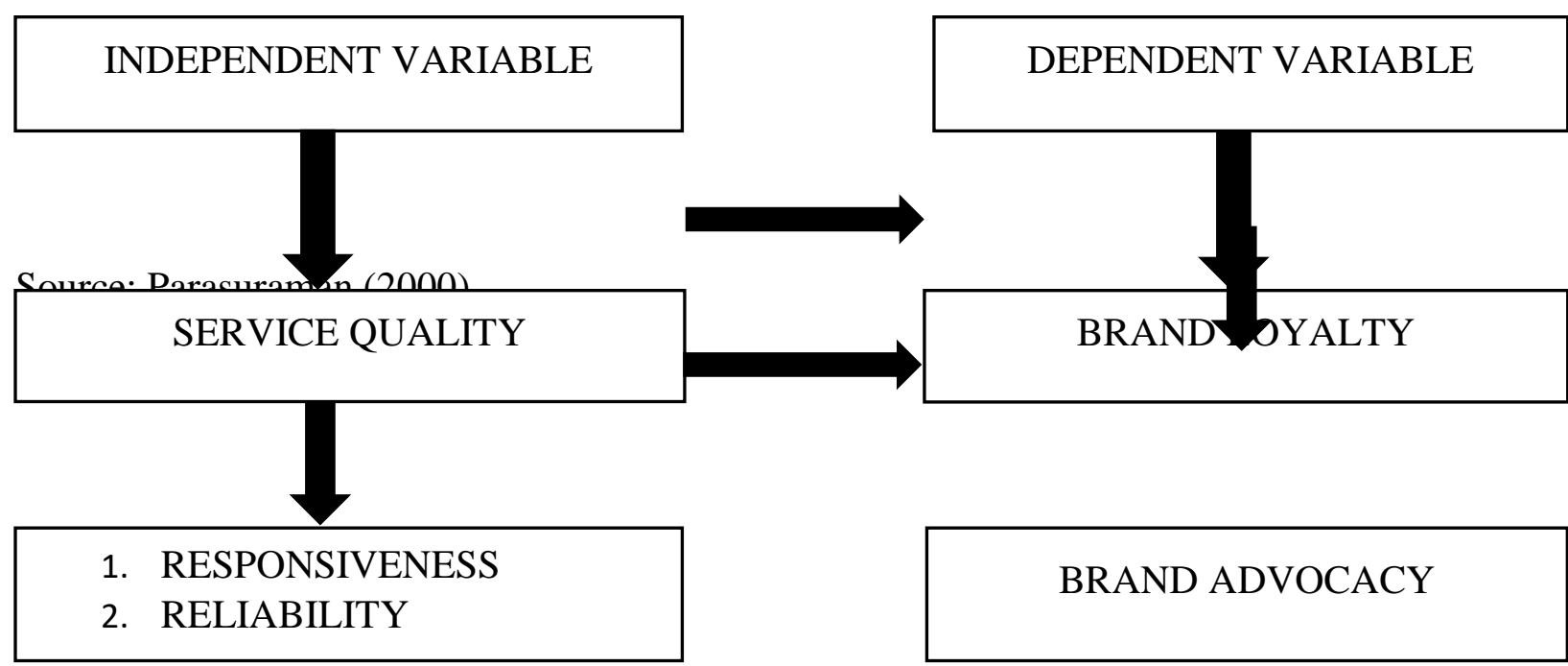

\section{Objectives}

1. To ascertain the relationship between responsiveness and brand advocacy.

2. To ascertain the relationship between reliability and brand advocacy.

\section{Research Questions}

1. To what extent does responsiveness influence brand advocacy?

2. To what extent does reliability influence brand advocacy?

\section{Hypotheses}

H1. There is no significant relationship between responsiveness and brand advocacy.

H2. There is no significant relationship between reliability and brand advocacy.

\section{LITERATURE REVIEW}

\section{Conceptual Review}

\section{Brand Loyalty}

Brand loyalty is a component of brand equity which is seen as the total value of all measures taken to differentiate the product and service offerings of a particular firm from that of their competitors. Aaker (1991) conceptualizes four main categories of brand equity which are Brand Associations, Brand Awareness, Perceived Quality, And Brand Loyalty, and also went further to state that brand loyalty is the most paramount of all the categories of brand equity. 
The concept of brand loyalty originated from the 1920s (Bennett, 2001, pp. 3). The definition considered to be most comprehensive and accepted was however given by Jacoby (1971, pp. 25), which conceptualizes it as "The biased (non-random) behavioral response (purchase) expressed over time by some decision-making unit with respect to one or more alternative brands out of a set of brands and is a function of psychological processes". This definition points to the belief that customers have a choice of what to purchase but decide to constantly patronize the product and service offerings of a particular brand intentionally.

The research of brand loyalty has developed along the confines of three main approaches; the behavioral approach, the attitudinal approach, and the composite approach to brand loyalty (Touzani \& Emessek, 2009). The behavioral approach brand loyalty is premised on the repetitive and systematic buying behaviour of customers overtime constituting an indication that the customer is loyal to the brand (Brown, 1952). The attitudinal approach to brand loyalty is focused on the positive mindset and perception the customers have about the brand in comparison to that of competitors, in relation to preference. It basically draws its focus from brand preference (Dick \& Basu, 1994). Finally, the composite approach to brand loyalty is a means to incorporate the attributes of the behavioral and attitudinal approaches to brand loyalty, and blend them into one. This was achieved by Jacoby (1971), when he conceptualized brand loyalty to be a buying behaviour that is repeated overtime by a customer in favor of a particular brand. This definition incorporates both the attributes of the behavioral and attitudinal approaches to brand loyalty.

\section{Brand Advocacy}

Brand advocacy has been studied based on two broad views reflecting both the view of the consumer and the organization perspective. In relation to the organizational perspective, according to Lawer and Knox (2006) "Brand advocacy is an advanced form of market-orientation that responds to the new drivers of consumer choice, involvement and knowledge. Brand advocacy aims to build deeper customer relationships by earning new levels of trust and commitment and by developing mutual transparency, dialogue and partnership with customers". This view focuses on the firm openly supplying the customers with all required information to make their choices on what to purchase as requested, with the intention that this will portray them in a trusting light and bolster the confidence of the customers in them. This seeks to establish a trusting relationship between the customers and the firm by opening all information for the customers to have access to it.

The second view, and basis for this research is focused on the view of the customers. According to Fullerton (2010), this view is focused on the intention and willingness of customers of a brand to speak on behalf of their favored brand, giving recommendations and high praises to their product and service offerings. It is seen as an advanced and more intense form of positive Word-Of-Mouth (WOM) given by customers in favor of a brand (Swan \& Oliver, 1989; Anderson, 1998; HarrisonWalker, 2001). Whereas both Brand Advocacy and WOM have been used interchangeably (Lawer and Knox, 2006) to mean the same thing, they are actually not the same but different in that Brand advocacy is an extreme representation of favor by a customer towards a brand (Noort, 2012). This differentiation comes into play mainly where in the case of WOM, the customer only tries to speak 
about the products of the brand, brand Advocacy involves actively trying to convince all who is ready to listen about the supremacy and value of the offerings of the favored brand, including jumping to the defense of the brand at all times when someone speaks against it in anyway (Fullerton, 2010; Urban, 2004, 2005,).

Further, Cross and Smith (1995) clarifies that brand advocacy is a product of the relationship between the brand and the customer, as its only customers with a strong relationship who identify with the brand that will be able to promote the brand and defend it against external attack. To further buttress this point, Peck et al., (1999) states that an advocate is one that actively recommends, defends, advertises, and markets a brand to others.

\section{The Origin of Brand Advocacy}

According to Urban (2005), Brand advocacy evolved out of the increase in the power of the customer in the business environment. In order to understand this origin of Brand advocacy, we will therefore study the growth and increase in the power of the customers in the business environment resulting.

\section{Growth of Customer Power}

The advent and usage of the internet was predicted, but the extent to the fundamentality of the use of the internet in the everyday life of individual customers was not. The internet created an avenue for all who are in need of information about an organization and its product and service offerings to access it easily through multiple sources, including other customers who have used the services or products of the firm. This has made it possible for many prospective buyers to search out relevant information, and past customers to give out information that can either support or destroy the sales intention of the firm. Urban (2005) went on to state that customers can research the product or service they intend purchasing months before approaching the firm all from the comfort of their homes, through the use of the internet facilities available to them.

This advent allows customers to find and compare competing brand easily, and the use of online reviews allow customers to find the best option for them at every given point in time. According to Urban (2005), more than $63 \%$ of leisure travelers and $69 \%$ of business travelers use the Internet for research. This points to the use of the internet to decide on patronizing a brand or the competing one based on the materials, resources, and reviews found online, and this is primarily a function of what customers who have used the product or service offerings of the firm make available online.

The internet also made it possible for customers to seek for products and services from a wide range or coverage of competing brands regardless of location or physical presence. Customers now have the ability to connect with multiple businesses functioning in the area they are interested in purchasing from with ease. The most significant element to the rise of customer power caused by the internet, is however the increased communication between customers, which has enabled them to boost customer collaborations and consultation to determine the effectiveness of the products 
and service offerings of a particular brand, as well as share advice. It was this increased communication that boosted the ability of WOM advertising.

Originally, a firm can lose customers to their lack of ability one at a time, or few at a time where a disgruntled customer decides to speak to some families and friends, but owing to the new ability of the customers to globally share their experiences with others, the effect is innumerable if negative. The internet has given the avenue for customers to leave comments and reviews on sellers and brands. This is especially true with E-Commerce websites such as Jumia, Konga, JIJI (even gives reviews and ratings on sellers), eBay, etc. in this case, star ratings are used to summarize the performance of a seller or product or a brand.

In totality, the reputation of a brand and its product offerings is largely dependent on the communication released by customers in relation to their experience with the firm, and this can either be in favor of the brand or an expression of dissatisfaction.

\section{Service Quality}

Service quality is the overall assessment of the performance of a service experienced by a customer against their initial expectation, and it is a preceding factor in determining the actual satisfaction a customer has at the consumption of a particular service offering (Parasuraman et al., 1988; Zeithaml \& Bitner, 1996). Parasuraman et al. (1988), went on to describe service quality as the ability of firms to satisfy the needs and wants of their customers at every given point in time. This stance was buttressed by Zeithaml et al. (1990), when they postulated that service quality is the perceived difference that stems from the difference between the expectations of customers, and the actual service experience gotten from the consumption of the service. This means that the quality of a service is a product of the judgement call of the customer based on the difference between their pre-existing service expectations, and the actual pleasure they derived from the consumption of the service. The quality rating is therefore in the ability of the firm to meet or exceed the service expectations of the customers of the organization. Services unlike products are produced and consumed simultaneously.

There are two necessary units to be present for a service to be produced and consumed (Hill 1987), and this is based on the fact that a service has certain characteristics such as perishability, intangibility, simultaneity, and heterogeneity (Palmer, 1995; Parasuraman, Zeithaml, \& Berry, 1985). These characteristics make the marketing activities of services to be different as the implications of them would be perceived in different light (Aniley \& Negi, 2010). Aniley and Negi (2010) further stated that whereas the final effects of a service can be retained by a consumer, the actual service cannot be retained after its production, as a result of the simultaneity of production and consumption. In this regard, the evaluation of the customers come to play in determining how the service is perceived in the long run. This evaluation is the basis of the importance of the expectations and the meeting and continuous exceeding of these expectations of the consumer by the marketing firm. This view was buttressed by Aniley and Negi (2010) where they stated expressly that customers have certain expectations of services of organizations that they consume, prior to the consumption, and that the determinant of the quality of the service is a product of the 
British Journal of Marketing Studies

Vol. 10, Issue 1, pp.47-63, 2022

Print ISSN: 2053-4043(Print),

Online ISSN: 2053-4051(Online)

meeting and exceeding the expectations of the service in the mind of the consumer. They further espoused that there are three underpinning factors in the formulating of the expectations of customers which are; the needs and wants of the customers, brand image and communicative activities of the organization, and the past experiences of the customer with the services of the organization.

Several research works have been done using two models to measure or dimension the subject matter service quality, which are the Gronroos Technical and Functional Quality framework, and the SERVQUAL model by Parasuraman, Zeithaml and Berry in the 1990s (Mudenda \& Guga, 2017). The Gronroos Technical and Functional Quality framework was argued to measure or dimension service quality based on the technical quality which focuses on the outcome of the service, and the functional quality which looks at the processes or delivery mechanisms for the rendering of the service (Mudenda \& Guga, 2017). The SERVQUAL model on the other hand, being developed by Parasuraman, Berry and Zeithaml (1991), initially dimensioned service quality into ten (10) items upon which customers are to make judgement on the quality of the service. Further research however conducted by Parasuraman (2000) reduced the ten (10) dimensions to a total of five (5) because of the finding that the original ten dimensions overlapped. These five (5) dimensions shall constitute the model for the deriving of the dimensions of service quality in the study.

Parasuraman (2000) described service quality using a five (5) dimension model which has been used by numerous researches to understand the intricacies of service quality in multiple industries such as banking, health, education, and others (Oyetunji, 2014; Samanhyia, 2014; Aikins, 2014). These dimensions have been stated by Parasuraman (2000) to be tangibility, reliability, responsiveness, assurance, and empathy. Bebko (2000) posits that reliability is the ability of the service providing organization to constantly provide or deliver the service in the form and standard advertised or communicated to the customers. Assurance on the other hand has been defined as the ability of the firm through her employees to exude confidence and trust in the hearts and minds of the customers, building trust and credibility (Mudenda \& Guga, 2017). Responsiveness has been looked at through the lens of the willingness of the service provider to assist and deliver quality service to their customers at all times (Parasuraman, Berry, \& Zeithaml, 1991). Curry and Sinclair (2002) posit that empathy is the personalized attention and care given to the customers by the service providers based on the emotionally specific deduced needs of the customers per time. Finally, Tangibility has been discussed by Allen (2008) to mean the physical appearance and elements of the service that are visible to the customer. The study shall however adopt the use of just two (2) out of the five (5) dimensions provided by the SERVQUAL model.

\section{Responsiveness}

According to Ramya, Kowsalya, and Dharanipriya (2019), responsiveness is the willingness to help customers and to provide prompt service. This dimension focuses in the attitude and promptness in dealing with customer requests, questions, complaints and problems. It also focuses on punctuality, presence, professional commitment etc., of the employees or staff. It can be calculated on the length of time customers wait for assistance, answers to questions etc. The

@ECRTD-UK https://www.eajournals.org/ Journal level DOI https://doi.org/10.37745/bjms.2013 
British Journal of Marketing Studies

Vol. 10, Issue 1, pp.47-63, 2022

Print ISSN: 2053-4043(Print),

Online ISSN: 2053-4051(Online)

conditions of responsiveness can be improved by continuously via the process of service delivery and employees' attitude towards requests of customers.

\section{Reliability}

Bebko (2000) defined Reliability as the ability of the service provider to constantly deliver the agreed services at a stable standard quality as previously communicated, advertised and expected by the customer. This was summarized in the work of Allen (2008) to be a product of dependability, and accurate performance. The two aforementioned point to the action of constantly giving out accurately standardized services to customers at every given point in time. This shows that for a service provider to be tagged reliable, he must be able to always meet up to the already set standard of the service to be provided to customers as previously communicated or experienced by the customers. In his work, Allen (2008) clearly stated that the service being provided must be dependable at all times, meaning that the service provider must at all times be able to exude dependency from the customers based on the services to be offered to them. He further posited that the services must be delivered in an accurate manner at all times.

Ramya, Kowsalya, and Dharanipriya (2019), went on to state that reliability is the ability to perform a promised service dependably and accurately, strengthening that posited by Bebko (2000). Their definition highlighted three areas of reliability; the promises of a service which can be either given by a service provider or based on Word of Mouth by other customers, the service provisions of the firm, and the problem resolutions brought about by the service offering. They further stated that customers prefer to transact with firms that keep to their promises in terms of performance and service delivery.

\section{THEORETICAL FRAMEWORK}

\section{Theory of Reasoned Action}

Fishbein and Ajzen (1975, 1980), developed the theory of reasoned action out of the failures of traditional attitude-behaviour research that consistently found weak correlations between attitudes and freewill behavioral tendencies. The main reason behind the development of the theory therefore is the explanation of freewill or volition behaviour. In trying to do this, the theory is to cover a wide range of behavioral tendencies, excluding all irrational ones such as behaviour based on cravings, impulse, habits, insanity, coercion, or spontaneity (Bentler \& Speckart, 1979; Langer, 1989). The theory focuses on all behaviour having a logical base or foundation, and dismisses all illogically based behavioral traits and expressions. In addition to this, all behaviour that is based on the availability of special resources, skills, opportunities, or collaborations, are as well excluded from the scope of the study of the theory (Liska, 1984). Every and all behaviour that doesn't fall into the scope of being individually logical in itself is discarded by this theory.

The theory is premised primarily on the notion that behavioral intent is the underlying factor of all behaviour exhibited by man, and this behavioral intent is a product of both the attitude of and individual, and the subjective norm which premises the behaviour. The attitudinal element here depicts the individual's independent view point towards the behaviour to be exhibited, whereas

@ECRTD-UK https://www.eajournals.org/ 
British Journal of Marketing Studies

Vol. 10, Issue 1, pp.47-63, 2022

Print ISSN: 2053-4043(Print),

Online ISSN: 2053-4051(Online)

the subjective norm depicts the external influence to the behaviour of the individual in question. (Jerold, Brian, and Kathryn, 2003).

\section{Empirical Review}

Chiosa and Anastasiei (2018), studied what takes consumers to develop brand advocacy on Facebook. The study found out that trust is the defining factor in the determination of the advocacy behaviour of customers is trust, which is premised on the reliability of the offerings of the brand. In their work, they stated that the most important element in getting a favorable brand attitude from customers, is to build trust by convincing the customers overtime that the brand offers products that will satisfy the needs of the customers, and will not harm the customers in any way, as well as communicate in a sincere manner.

Cant, Machado, and Seaborne (2014), studied Brand Advocacy, using Apple as a case study in South Africa, Pretoria. The study found out that advocacy behaviour of apple customers was informed or preceded by the belief that the products are beautifully designed, reliable, and have he necessary features to satisfy their needs at any given point in time. It was also noted that the brand was trusted by its customers, and this was accruing to the capacity of the brand to keep its promises. Khamwon and Masri (2020) studied Brand Experience, Brand Love, and Brand Advocacy in Thailand. The study concluded that the experiences of a customer with regards to a product or service, has a direct and indirect influence on advocacy on the part of the consumer.

Karunanayaka, Arokiasamy, and Masri, (2018) studied the effect of perceived value-in-use in advocacy behavior of private higher education institutions in Malaysia. The findings of the research showed that for customer advocacy behaviour to be evident in customers of a brand, there must be trust and clarity of roles. Clarity of roles relate to the understanding of the part customers are to play to the success and optimal experience gotten from the consumption of a product or service offering, whereas trust is concerned with how the customers see the brand to be socially responsible.

Sashi, Brynildsen and Bilgihan (2019) carried out a research on Social media, customer engagement and advocacy in Florida USA, where they found out that listening and responding promptly to customers has an impact on the advocacy behaviour of customers as customers expect more than the acknowledgement of the existence of a problem, and want the resolution of problems speedily. They further stated that the speedy response of brands to the complaints of customers have an impact on the advocacy. Afridi, and Khattak (2015) studied Impact of Trust on Customer Advocacy in the health sector of Peshawar. The study uncovered that a strong correlation exists between trust and customer advocacy.

Hassan, Rafi, and Kazmi (2016) studied the Impact of Differentiated Customer Service, Brand Trust, Brand Commitment, and Brand Salience on Brand Advocacy in Pakistan and found out that differentiated customer service has a significant impact on customer advocacy.Sommakettarin, and Khamwon (2020) studied Service Quality, Customer Experience Quality, Customer Satisfaction and Brand Advocacy. The study was carried out in Thailand, where it was focused on the plastic

@ECRTD-UK https://www.eajournals.org/ Journal level DOI https://doi.org/10.37745/bjms.2013 
surgery industry. The findings clearly stated that service quality was an important factor in determining whether or not a customer would behave in an advocative manner or not.

\section{METHODOLOGY}

The research is a descriptive research aimed at ascertaining the nature of the relationship between service quality and brand loyalty in Bayelsa State of Nigeria, and as such utilizes the Pearson correlation statistical tool aided by the Windows SPSS computer software to analyze primary data gotten from the administration of questionnaire to a total of 140 bank customers. The analysis relied on the following model which has been in wide use by previous researchers (Etale \& Tiemo, 2021; Etale \& Edoumiekumo, 2021; Etale \& Adah-Marcus, 2021 and Etale \& Tueridei, 2021):

$B R A D=f(R E S P, R E L I)$

Thus expressing brand advocacy as a function of responsiveness and reliability. The above model was translated into a mathematical equation as stated below:

$B R A D=\beta_{o}+\beta_{1} R E S P+\beta_{2} R E L I+\mu$

Where:

$B R A D=$ Brand advocacy, the response variable as a measure brand loyalty,

$R E S P=$ Responsiveness an explanatory variable and one of the measures of service quality,

$R E L I=$ Reliability the second explanatory variable and another measure of service quality,

$\beta_{o}=$ The constant term

$\beta_{1}$ and $\beta_{2}=$ The correlation coefficients that would determine the nature of the relationship between the independent variables and response variable,

$\mu=$ The error term of the equation

\section{DATA ANALYSIS AND INTERPRETATION}

This part of the paper highlights the analysis and findings of the of the research work based on the statistical analysis of data derived from the administration of questionnaire to a total of 140 bank customers whereby a total of 130 copies of the questionnaire were recovered that formed the basis for this analysis.

The demographics analysis turned up the following results:

\section{Gender}

\begin{tabular}{llllll} 
& & Frequency & Percent & Valid Percent & Cumulative Percent \\
\hline \multirow{4}{*}{ Valid } & Male & 81 & 62.3 & 62.3 & 62.3 \\
\cline { 2 - 6 } & Female & 49 & 37.7 & 37.7 & 100.0 \\
\cline { 2 - 5 } & Total & 130 & 100.0 & 100.0 & \\
\hline
\end{tabular}

The total recovered questionnaires amounted to 130, where 81 respondents which represents $62.3 \%$ of the total fell under the confines of the male gender, whereas 49 respondents which represents $37.7 \%$ of the total fell under the female gender. 
British Journal of Marketing Studies

Vol. 10, Issue 1, pp.47-63, 2022

Print ISSN: 2053-4043(Print),

Online ISSN: 2053-4051(Online)

Age

\begin{tabular}{llllll} 
& & Frequency & Percent & Valid Percent & Cumulative Percent \\
\hline \multirow{4}{*}{ Valid } & Under 20 Years & 9 & 6.9 & 6.9 & 6.9 \\
\cline { 2 - 6 } & $21-30$ years & 82 & 63.1 & 63.1 & 70.0 \\
\cline { 2 - 6 } & 30 years and above & 39 & 30.0 & 30.0 & 100.0 \\
\cline { 2 - 5 } & Total & 130 & 100.0 & 100.0 &
\end{tabular}

The age distribution of the questionnaires recorded that 9 respondents out of the total which represents $6.9 \%$ were below the age of 20,82 which represents $63.1 \%$ fell within the ages of $21-$ 30 , and 39 respondents which represents $30 \%$ were 30 years and above.

Marital Status

\begin{tabular}{llllll} 
& & Frequency & Percent & Valid Percent & Cumulative Percent \\
\hline \multirow{7}{*}{ Valid } & Single & 108 & 83.1 & 83.1 & 83.1 \\
\cline { 2 - 6 } & Married & 15 & 11.5 & 11.5 & 94.6 \\
\cline { 2 - 5 } & Divorced & 7 & 5.4 & 5.4 & 100.0 \\
\cline { 2 - 4 } & Total & 130 & 100.0 & 100.0 &
\end{tabular}

The analysis of the data showed that a total of 108 respondents representing $83.1 \%$ of the whole were single, 15 respondents representing $11.5 \%$ were married, and 7 respondents representing $5.4 \%$ were divorced.

\section{Employment Status}

\begin{tabular}{llllll} 
& & Frequency & Percent & Valid Percent & Cumulative Percent \\
\hline \multirow{4}{*}{ Valid } & Student & 52 & 40.0 & 40.0 & 40.0 \\
\cline { 2 - 6 } & Unemployed & 30 & 23.1 & 23.1 & 63.1 \\
\cline { 2 - 5 } & Self-employed & 26 & 20.0 & 20.0 & 83.1 \\
& Employed & 21 & 16.2 & 16.2 & 99.2 \\
& Retired & 1 & .8 & .8 & 100.0 \\
\hline & Total & 130 & 100.0 & 100.0 & \\
\hline
\end{tabular}

The study demographics showed that $52(40 \%)$ respondents were students, $30(23.1 \%)$ respondents were unemployed, 26 (20\%) respondents were self-employed, 21 (16.2\%) respondents were employed, and $1(0.8 \%)$ respondent was retired.

\section{Do you have a bank account}

\begin{tabular}{lllll} 
& Frequency & Percent & Valid Percent & Cumulative Percent \\
\hline Valid yes & 130 & 100.0 & 100.0 & 100.0 \\
\hline
\end{tabular}

The study demographics showed that all respondents totaling 130 (100\%) have bank accounts.

\section{Frequent mobile app}

\begin{tabular}{llllll} 
& & Frequency & Percent & Valid Percent & Cumulative Percent \\
\hline \multirow{4}{*}{ Valid } & 5 & 3.8 & 3.8 & 3.8 \\
\cline { 2 - 5 } & never & 26 & 20.0 & 20.0 & 23.8 \\
\cline { 2 - 5 } & once a month & 7 & 5.4 & 5.4 & 29.2 \\
\hline bimonthly & 74 & 41.5 & 41.5 & 70.8 \\
\cline { 2 - 5 } & weekly & 29.2 & 29.2 & 100.0 \\
\hline daily & 38 & 100.0 & 100.0 & \\
\hline
\end{tabular}


The study demographics showed that $5(3.8 \%)$ respondents never use the bank mobile app, 26 (20\%) respondents use the mobile app an average of once a month, 7 (5.4\%) respondents use the mobile app an average of two times a month, 54 (41.5\%) respondents use the mobile app weekly, and $38(29.2 \%)$ respondents use the mobile app on a daily basis.

\section{Frequent banking hall}

\begin{tabular}{llllll} 
& & Frequency & Percent & Valid Percent & Cumulative Percent \\
\hline Valid & never & 23 & 17.7 & 17.7 & 17.7 \\
\cline { 2 - 6 } & once a month & 64 & 49.2 & 49.2 & 66.9 \\
\cline { 2 - 6 } & bimonthly & 14 & 10.8 & 10.8 & 77.7 \\
\cline { 2 - 6 } & weekly & 15.4 & 15.4 & 93.1 \\
\cline { 2 - 4 } & 9 & 6.9 & 6.9 & 100.0 \\
\hline Total & 130 & 100.0 & 100.0 &
\end{tabular}

The study demographics showed that 23 (17.7\%) respondents never visit the banking hall, 64 (49.2\%) respondents visit the banking hall monthly, 14 (10.8\%) visit the banking hall bimonthly, $20(15.4 \%)$ visit the banking hall weekly, and $9(6.9 \%)$ visit the banking hall daily.

\section{Frequent contact customer care}

\begin{tabular}{llllll} 
& & Frequency & Percent & Valid Percent & Cumulative Percent \\
\hline \multirow{6}{*}{ Valid } & once a month & 105 & 80.8 & 80.8 & 80.8 \\
\cline { 2 - 6 } & bimonthly & 14 & 10.8 & 10.8 & 91.5 \\
\cline { 2 - 6 } & weekly & 2 & 1.5 & 1.5 & 93.1 \\
\cline { 2 - 5 } & daily & 9 & 6.9 & 6.9 & 100.0 \\
\cline { 2 - 5 } & Total & 130 & 100.0 & 100.0 & \\
\hline
\end{tabular}

The study demographics showed that

\section{Test of Hypotheses}

H1. There is no significant relationship between responsiveness and brand advocacy.

\section{Correlations}

\begin{tabular}{llll} 
& & Responsiveness & Brand Advocacy \\
\hline Responsiveness & Pearson Correlation & 1 & $.965^{\star *}$ \\
\cline { 2 - 4 } & Sig. (2-tailed) & .000 \\
\cline { 2 - 4 } & $\mathrm{N}$ & 130 & 130 \\
\hline Brand_Advocacy & Pearson Correlation & $.965^{* *}$ & 1 \\
\cline { 2 - 4 } & Sig. (2-tailed) & .000 & 130 \\
\cline { 2 - 4 } & $\mathrm{N}$ & 130 & \\
\hline
\end{tabular}

${ }^{*}$. Correlation is significant at the 0.01 level (2-tailed).

The analysis of the data on the relationship between responsiveness and brand advocacy using the Pearson correlation coefficient shows a significant strong positive relationship between responsiveness and brand advocacy. This means that for a firm to have customers that speak on its behalf will and defend it as advocates, they must possess the attribute of responsiveness. This means that there is a significant relationship between responsiveness and brand advocacy, invalidating the first null hypotheses. 
H2. There is no significant relationship between reliability and brand advocacy. Correlations

\begin{tabular}{llll} 
& & Reliability & Brand Advocacy \\
\hline Reliability & Pearson Correlation & 1 & $.992^{* *}$ \\
\cline { 2 - 4 } & Sig. (2-tailed) & & .000 \\
\cline { 2 - 4 } & $\mathrm{N}$ & 130 & 130 \\
\hline Brand_Advocacy & Pearson Correlation & $.992^{* *}$ & 1 \\
\cline { 2 - 4 } & Sig. (2-tailed) & .000 & 130 \\
\cline { 2 - 4 } & $\mathrm{N}$ & 130 &
\end{tabular}

**. Correlation is significant at the 0.01 level (2-tailed).

The analysis of the data on the relationship between reliability and brand advocacy using the Pearson correlation coefficient shows a significant strong relationship between the variables, where the non-existence or existence of reliability has a direct impact on brand advocacy of customers. This invalidates the second null hypotheses of the study by establishing the fact that there is a significant relationship between reliability and brand advocacy.

\section{CONCLUSION AND RECOMMENDATIONS}

\section{Conclusion}

The study evaluates the relationship between service quality and Brand loyalty using responsiveness and reliability as dimensions of service quality, and brand advocacy as a measure of Brand loyalty and administered questionnaires to customers of three banks in Yenagoa, Bayelsa State of Nigeria to serve as a focus for the derivation of data upon which analysis will be done and findings drawn. The analysis of the data gotten showed that both responsiveness and reliability have a strong relationship with brand advocacy. The study therefore concludes that service quality has a significantly positive relationship with Brand loyalty.

\section{Recommendations}

Based on the findings of the research, the following recommendations are given:

1. Banks should give prompt and quick response to its customers ${ }^{e e}$ compliant by creating a simple and fast compliant handling system.

2. Banks must let its customers feel safe and secured in any transaction.

3. Banks should create a strong feedback system that enables them to relate effectively with customers and understand the $m$ better.

4. Banks should fasten their service processes.

\section{REFERENCES}

Aaker, D. A., 1991, Managing Brand Equity, The Free Press, New York

Afridi, S.A., Khattak, A., (2015). Impact of Trust on Customer Advocacy: A Study Regarding Health Sector of Peshawar. Abasyn Journal of Social Sciences. Vol 8, Issue 2, Page 855862.

Aikins, I. (2014). Assessing the Role of Quality Service Delivery in Client Choice for Healthcare: A Case Study of Bechem Government Hospital and Green Hill Hospital. European Journal of Logistics Purchasing and Supply Chain Management, 2(3), 1-23. 
British Journal of Marketing Studies

Vol. 10, Issue 1, pp.47-63, 2022

Print ISSN: 2053-4043(Print),

Online ISSN: 2053-4051(Online)

Allen, M. (2008). Quality control Handbook, (4th ed.). New York: McGraw Hill.

Anderson, E. (1998). Customer Satisfaction and Word of Mouth. Journal of Service Research, $1(1), 5-17$.

Aniley, B., and Negi, R., (2010). Service Quality Attributes Affecting Passengers Satisfaction with HIGER City Bus. Eurasian Journal of Business and economics, Vol. 2, pp. 70-98.

Bebko, C. P. (2000). Service intangibility and its impact on consumer expectations of service quality. Journal of Services Marketing, 14(1), 9-26.

Bennett, R. (2001). A Study of Brand Loyalty in the Business-to-Business Services Sector

Bentler, P.M., and Speckart, G. (1979). Models of Attitude-Behaviour Relations. Psychological Review, 86, 425-464.

Brown, G., (1952), “Brand Loyalty Fact or Fiction”, Advertising Age, Vol. 26, January, pp. 7576.

Cant, M.C., Machado, R., Seaborne, H.C., (2014). Brand Advocates -An Apple Phenomenon? An Exploratory Study on Brand Advocacy Amongst Apple Consumers. Corporate Ownership \& Control / Volume 11, Issue 2, Page 535-541.

Chang, T. Z., \& Wildt, A. R. (1994). Price, product information, and purchase intention: An empirical study. Journal of the Academy of Marketing science, 22(1),16-27.

Chiosa, A.R., Anastasiei, B., (2018). What Takes Consumers to Develop Brand Advocacy on Facebook. Network Intelligence Studies Volume VI, Issue 12, Page 131-140.

Cross, R., Smith, J., (1995). Customer Bonding: Pathway to Lasting Customer Loyalty. NTC Business Books, Linwood.

Curry, A. \& Sinclair, E. (2002). Assessing the quality of physiotherapy services using SEVQUAL.

Dick, A.S., Basu, K., (1994), "Customer Loyalty: Toward an Integrated Conceptual Framework", Journal of the Academy of Marketing Science, Vol. 22, No. 2, pp. 99-113.

Ennew, C. T., \& Binks, M. R. (1999). Impact of participative service relationships on quality, satisfaction and retention: an exploratory study. Journal of Business Research, 46(2), 121132.

Etale, L. M. \& Adah-Marcus, P. O. (2021) Environmental investments and financial performance of listed consumer services sector firms in Nigeria, IOSR Journal of Business and Management (IOSR-JBM), 23(11/11), 01-10

Etale, L. M. \& Edoumiekumo, A. R. (2021) Environmental accounting and financial performance nexus of Nigerian Stock Exchange listed oil and gas sector companies, IOSR Journal of Business and Management (IOSR-JBM), 23(8/5), 32-38

Etale, L. M. \& Tiemo, H. L. J. (2021) Environmental accounting and performance of listed financial services sector firms in Nigeria, IOSR Journal of Economics and Finance (IOSR$J E F), 12(4 / 7), 52-58$

Etale, L. M. \& Tueridei, S. W. (2021) Cost of capital and environmental accounting practices of listed oil and gas companies in Nigeria, IOSR Journal of Economics and Finance (IOSR$J E F), 12(6 / 11), 48-54$

Erciş, A., Ünal, S., Candan, F. B., \& Yıldırım, H. (2012). The Effect of Brand Satisfaction, Trust and Brand Commitment on Loyalty and Repurchase Intentions. Procedia-Social and Behavioral Sciences, 58, 1395-1404.

@ECRTD-UK https://www.eajournals.org/

Journal level DOI https://doi.org/10.37745/bjms.2013 
British Journal of Marketing Studies

Vol. 10, Issue 1, pp.47-63, 2022

Print ISSN: 2053-4043(Print),

Online ISSN: 2053-4051(Online)

Fishbein, M., Ajzen, I. (1975). Beliefs, Attitude, Intention and Behaviour: An Introduction to Theory and Research. Reading, MA: Addison Wesley.

Fishbein, M., Ajzen, I. (1980). Predicting And Understanding Consumer Behaviour: Attitude Behaviour Correspondence. In J. Ajzen and M. Fishbein (Eds.), Understanding Attitudes and Predicting Social Behaviour (pp. 148-172). Englewood Cliffs, NJ: Prentice Hall.

Fullerton, G. (2010). Creating advocates: The roles of satisfaction, trust and commitment. Journal of Retailing and Consumer Services, 18(1), 92-100

Gotlieb, J. B., Grewal, D., \& Brown, S. W. (1994). Consumer satisfaction and perceived quality: complementary or divergent constructs? Journal of applied psychology, 79(6), 875.

Giddens, N. (2002). Brand Loyalty. Ag Decision Maker. Iowa State University Extensions,5(54), $1-2$.

Hallowell, R. (1996). The relationships of customer satisfaction, customer loyalty, and profitability: an empirical study. International journal of service industry management, 7(4), 27-42.

Harrison-Walker, L. (2001). The Measurement of Word-of-Mouth Communication and an Investigation of Service Quality and Customer Commitment as Potential Antecedents. Journal of Service Research, 4(1), 60-75.

Hassan, M., Rafi, A., Kazmi, S.S., (2016). Impact of Differentiated Customer Service, Brand Trust, Brand Commitment, and Brand Salience on Brand Advocacy. International Review of Management and Marketing, Vol 6, Special Issue (S4), Page 232-238.

Hill, P., (1987). The service sector: Current state of knowledge and research frontiers. In Conceptual issues in service sector research: A symposium, edited by Herbert G. Grubel. The Frasier Institute.

Jacoby, J. (1971). A model of multi-brand loyalty. Journal of Advertising Research, 11(3), 25-61.

Jerold, L.H., Brian, J.H, Kathryn, L.G, (2003). The Theory of Reasoned Action. Theories of Persuasion, 14, 259-286.

Karunanayaka, D.P.C., Arokiasamy, L., Masri, R., (2018). The effect of perceived value-in-use in advocacy behavior of private higher education institutions in Malaysia: A conceptual paper. SHS Web of Conferences 56, $02001 \quad$ (2018) https://doi.org/10.1051/shsconf/20185602001 ICLM 2018.

Khamwon, A., Masri, P., (2020). Brand Experience, Brand Love, and Brand Advocacy: A Case of Premium Smartphone. International Journal of Technology Management and Information System, Vol. 2, No. 3, 21-26.

Langer, E.J. (1989). Mindfulness Reading. Reading MA: Merloyd Lawrence Books.

Lawer, C., and Knox, S., (2006). Customer advocacy and brand development. Journal of Product \& Brand Management. 15:2, pp. 121-129.

Liska, A.E. (1984). A Critical Examination of The Causal Structure of The Fishbein-Ajzen Model. Social Psychology Quarterly, 47, 61-74.

Mudenda, C., and Guga, D., (2017). An Assessment of the Relationship between Service Quality and Customer Satisfaction-A Case of a Public Passenger Road Transportation Company in Zambia. International Review of Management and Business Research. Vol. 6, Issue.2, pp. 541-555.

@ECRTD-UK https://www.eajournals.org/

Journal level DOI https://doi.org/10.37745/bjms.2013 
British Journal of Marketing Studies

Vol. 10, Issue 1, pp.47-63, 2022

Print ISSN: 2053-4043(Print),

Online ISSN: 2053-4051(Online)

Oyetunji, E. O. (2014). Comparison of Service Quality of two Commercial Banks in Upper East Region of Ghana. Proceedings of the 2014 International Conference on Industrial Engineering and Operations Management. Bali, Indonesia. 782 -792.

Palmer, A., (1995). Service marketing: Principles and practice. New Jersey: Prentice-Hall.

Parasuraman, A., (2000). Technology readiness index (TRI): A multiple-item scale to measure readiness to embrace new technologies. Journal of Service Research, 2(4), 307-20.

Parasuraman, A., Berry, L. L., \& Zeithaml, V. A. (1991). Refinement and reassessment of the SERVQUAL scale. Journal of Retailing,64 (4), 420-450.

Parasuraman, A., Zeithaml V.A., and Berry L.L., (1985). A conceptual model of service quality and its implications for future research. Journal of Marketing, Vol. 49 (Fall): 41-50.

Parasuraman, A., Zeithaml, V.A. and Berry, L.L. (1988), "SERVQUAL: a multiple-item scale for measuring consumer perceptions of service quality", Journal of Retailing, Vol. 64 No. 1, Spring, pp. 12-40.

Patterson, P. G., \& Spreng, R. A. (1997). Modelling the relationship between perceived value, satisfaction and repurchase intentions in a business-to-business, services context: an empirical examination. International Journal of Service Industry Management, 8(5), 414434.

Peck, H., Payne, A., Christopher, M., Clark, M. (1999). Relationship Marketing: Strategy and Implementation. Butterworth-Heinemann, Oxford.

Ramya, N., Kowsalya, A., and Dharanipriya, K., (2019). Service Quality and Its Dimensions. EPRA International Journal of Research and Development (IJRD). Vol. 4(2), pp 38-41.

Rosenberg, L., Czepiel, J.A. (1984) Marketing Approach to Customer Retention. Journal of Consumer Marketing,1(2), 45-51

Saif, T., Ahmed, M., Shareef, S. and Khalid, R. (2018). "Characteristics of Brand Loyalty: A Study on Apparel Industry", Mediterranean Journal of Basic and Applied Sciences (MJBAS) Volume 2, Issue 2, Pages 64-91, April-June 2018

Samanhyia, S. (2014). Assessing The Educational Quality Gap in Ghana: Evidence from The Ashanti Region. International Journal of Economics, Commerce and Management, 2(2).

Santouridis, I. \& Trivellas, P. (2010). Investigating the impact of service quality and customer satisfaction on customer loyalty in mobile telephony in Greece. The TQM Journal, 22 (3), 330-343

Sashi, C.M., Brynildsen, G., Bilgihan, A., (2019). Social media, customer engagement and advocacy: An empirical investigation using Twitter data for quick service restaurants. International Journal of Contemporary Hospitality Management Vol. 31 No. 3, Page 12471272.

Sommakettarin, A., Khamwon, A., (2020). Service Quality, Customer Experience Quality, Customer Satisfaction and Brand Advocacy. International Journal of Business and Economy e-ISSN: 2682-8359 | Vol. 2, No. 3, 31-37, http://myjms.moe.gov.my/index.php/ijbec

Swan, J., \& Oliver, R. (1989). Postpurchase Communications by Consumers. Journal of Retailing, 65(4), 516-533.

@ECRTD-UK https://www.eajournals.org/

Journal level DOI https://doi.org/10.37745/bjms.2013 
Vol. 10, Issue 1, pp.47-63, 2022

Print ISSN: 2053-4043(Print), Online ISSN: 2053-4051(Online)

Touzani M., Emessek A., (2009). Brand Loyalty: Impact of Cognitive and Affective Variables. The Annals of "Dunarea de Jos" University of Galati Fascicle I - 2009. Economics and Applied Informatics. Years XV - ISSN 1584-0409

Urban, G. (2004). The Emerging Era of Customer Advocacy. MIT Sloan Management Review, 45(2), 77-82.

Urban, G. (2005). Customer Advocacy: A New Era in Marketing? Journal of Public Policy \& Marketing, 24(1), 155-159.

Zeithaml, V.A. and Bitner, M.J., (1996), Services Marketing, international edition, McGraw Hill, New York, NY and London.

Zeithaml, V.A., Parasuraman, A. and Berry, L.L., (1990), Delivering quality service: Balancing Customer perceptions and expectations, Free Press, New York, NY. 